\title{
Municipal Neoliberalism and Municipal Socialism: Urban Political Economy in Latin America
}

\author{
Benjamin Goldfrank and Andrew Schrank \\ Seton Hall University University of New Mexico \\ Prepared for delivery at the 2006 Annual Meeting of the American Political Science \\ Association, August 30th-September 3, 2006.
}

\begin{abstract}
The following paper identifies two different urban policy regimes in Latin Americaneoliberal and socialist - and traces their origins to the distinct interests and capacities of local elites and activists in the region's cities in the mid-to-late twentieth century. While agricultural and commercial interests paid a high price for the growth of importsubstituting industrialization, and therefore deployed free trade zones (and similar institutions) in traditional export centers in the 1960s and 1970s, their industrial rivals bore the brunt of austerity and adjustment in the free market era, and therefore adopted compensatory measures designed to increase the "social wage" in the 1980s and 1990s. Examples are drawn from municipalities in Brazil, the Dominican Republic, Mexico, Uruguay, and Venezuela and call the conventional portrait of impotent Latin American cities - and omnipotent central governments - into question.
\end{abstract}




\section{Introduction}

A substantial and growing body of literature identifies and accounts for the emergence of distinct types of urban political economy in the late twentieth century world system. For instance, Peter Evans (2002) and his colleagues extol the virtues of "livable cities." Saskia Sassen (1991) discusses the contradictions of "global cities." Don Pinnock (1989) labels Cape Town a "garrison city.” And Richard Florida (2002; see also Scott 2006) has made a veritable industry out of the so-called creative city. ${ }^{1}$ The inventory of names and labels threatens to outgrow the population of cities in need of classification, however, and taxonomic caution is therefore in order. After all, New York has simultaneously been classified as "global," "post-Fordist," "creative," and "divided" (Sassen 1991; Mayer 1991; Florida 2002; Fainstein 1992), and Los Angeles appears to earn a new adjective or sobriquet almost every other year (Soja 1995; Low 1997).

The following paper therefore tempts fate by labeling and analyzing the dialectical evolution of two different types of urban political economy-neoliberal and socialist — in late twentieth century and early twenty first century Latin America. Part 1 identifies the ideological differences between the two types of city as well as their implications for public policy. While neoliberal cities prioritize accumulation, and therefore use tax breaks, regulatory rollbacks, and the repression of organized labor to attract and retain foreign direct investment, their socialist rivals prioritize distribution, and therefore use social funds, microcredit arrangements, and participatory institutions to employ and empower their citizens. Part 2 treats the emergence of municipal

\footnotetext{
${ }^{1}$ We could go on. Tim Hall and Phil Hubbard (1996; Harris 1997) weigh the costs and benefits of "entrepreneurial cities." Gordon MacLeod (2002) expects entrepreneurial cities to be transformed into "revanchist cities." Susan Christopherson (1994) identifies and illuminates "fortress cities." And a host of scholars have discussed the "post-Fordist city" (see, e.g., Mayer 1994).
} 
neoliberalism as a secondary city or hinterland reaction to the growth of urban primacy or bias in the middle of the twentieth century. While industrial interests in traditional population centers like Mexico City and São Paulo reaped the rewards of importsubstituting industrialization (ISI), and therefore organized to defend their gains, their agricultural and commercial rivals paid a high price for tariffs and foreign exchange controls, and therefore offset or compensated for the growth of urban bias by deploying free trade zones (and similar institutions) in secondary cities like Juárez and Manaus. Part 3 traces the origins of municipal socialism to the breakdown of ISI and the arrival of the debt crisis and national neoliberal policies in the late twentieth century. While municipal neoliberals had already embraced foreign trade and investment, and therefore welcomed structural adjustment at the national level, their socialist rivals feared globalization, and responded with a variety of compensatory measures designed to increase the "social wage," not only in Mexico City and São Paulo but in other major cities like Lima, Montevideo, and Caracas. And, finally, Part 4 concludes by offering a Polanyian interpretation of the seemingly odd convergence of neoliberal and socialist policy tendencies in some municipalities today-suggesting that, whatever their ideological preferences, municipal authorities must balance accumulation and distribution if they are to survive and prosper in a globalized world. If not, both national and local authorities will continue to engage in the bitter struggles over policy responses to globalization currently under way in Venezuela and Bolivia.

\section{Intellectual context}

Our paper departs from a puzzling feature of the literature on Latin American cities. While municipal authorities have traditionally been deprived of political and 
economic resources, and have thereby garnered a reputation for impotence or even indolence, they have at times encouraged or exploited experiments in social and economic policymaking, and have thereby anticipated — rather than reacted to - national policy imperatives. Take, for example, the case of free market economic policies. Municipal authorities established or encouraged the growth of free trade zones (FTZs) in Mexico, Central America, and the Dominican Republic in the 1960s and 1970s — a full decade before the debt crisis put paid to ISI at the national level (World Bank 1992, Table A3).

Nor are FTZs isolated examples of municipal neoliberalism. Brazilian and Argentine municipalities have been competing for foreign transplants for well over a quarter of a century (Business Week 1979; Schumacher 1983; Lee 1989; Wheatley 1997). Andean city managers have called for the decentralization of economic decision making authority more broadly (Catanese 1973; Economist 1987, 2001; Forero 2004; Markey 2005; Eaton 2007). And municipal and provincial policymakers have appeased or attracted business by adopting de facto, if not necessarily de jure, regulatory rollbacks throughout the region (see, e.g., Tendler 2002 on Brazil; and Piore 2005 on Mexico).

As the twentieth century progressed, however, other Latin American cities eschewed investment incentives in favor of distributive politics, and the region therefore increasingly played host to "socialist" as well as recognizably neoliberal cities. Participatory budgeting initiatives have proliferated from southern Brazil to the rest of the region (Wampler and Avritzer 2004; Braütigam, 2004; Goldfrank 2006). Recently decentralized public services like health care and education have been fortified, in at least some cases, at the local level (Ocampo and Martín 2003, Ch. IX). And municipally 
administered social funds have allegedly compensated the poor for the high cost of free market reform throughout the region (Siri 2000; Tendler and Serrano 1999; Tendler 2000; Menocal 2004).

Efforts to compensate and empower slum dwellers reached their apogee in the late 1990s, however, and arguably catapulted their social democratic champions to power in subsequent national elections. With this rise of the left at the national level and the corresponding decline of neoliberal hegemony, Latin American cities stand poised for a new wave of conservative counterreaction (see, e.g., Weitzman [2006] on Bolivia).

We therefore begin to distinguish municipal socialism from municipal neoliberalism by highlighting three important - if by no means universal-shortcomings in the existing social scientific literature. First, the existing literature tends to treat local experiments in social and economic policy as symptoms of-rather than precursors ofnational initiatives. For example, Alejandro Portes and Brian Roberts trace the growth of export platforms like Tijuana, Iquique, and Salvador to "the abrupt end of the autonomous industrialization project promoted by ISI in the early 1980s" (Portes and Roberts 2005, p. 45 as well as pp. 53-55). Judith Tendler holds that social funds are administered not by municipal authorities per se but by central government bureaucrats who "work through local governments" when they are "headed by the party faithful" and bypass local governments when they are not (Tendler 2000, p. 116). And Rosemary Thorp notes that the impulse for decentralization "has always come from the centre-in that sense it is always top down" (Thorp quoted in Menocal 2004, p. 727).

Second, the existing literature tends to treat subnational social and economic policies in isolation from one another (see Heller 1995 for an important exception to the 
rule based on Asian materials). Students of municipal neoliberalism rarely engage, let alone study, the question of social policy and students of municipal socialism rarely entertain, let alone study, the question of accumulation. Nowhere is the dialogue of the deaf - to which we have admittedly been party_-more apparent than in the expansive and all but entirely distinct literatures on "subnational industrial policy" (Montero 2001) and “participatory budgeting” in Brazil.

And, finally, the existing literature is all but silent on the conditions for subnational success and failure. While many analysts examine only successful examples of local experiments, and thereby render themselves vulnerable to charges of selection bias (see King, Keohane, and Verba 1994), others treat local experiments as policy outcomes to be explained, and thereby sidestep the question of their subsequent success and failure.

We call each of the aforementioned practices into question by noting that subnational social and economic policy initiatives: (1) often anticipate, rather than respond to, their national analogs; (2) are almost invariably in dynamic tension with each other; and (3) are necessarily circumscribed by social and political organization. Our stylized model of subnational experimentation is therefore straightforward. We hold that national social and economic policy regimes foster regionally distinctive winners and losers. While the winners reap the rewards of the national efforts, and therefore organize to exploit and defend their gains in national as well as local political space, the losers pay the price, and therefore attempt to cushion the blow by adopting or defending contrary policies at the local level whenever they can. 
We therefore treat municipal neoliberalism and municipal socialism neither as products nor as symptoms of their national analogs but as subnational reactions to their national rivals: import-substituting industrialization and free market reform respectively. After all, ISI privileged industrial interests in large cities and their satellites and punished traditional agricultural and commercial interests in the hinterland (Hirschman 1968; Sheahan 1987). ${ }^{2}$ Agricultural and commercial elites responded to the perceived injustice by demanding and exploiting compensatory arrangements including — but not limited to-free trade zones (Schrank 2005). And the oldest export platforms in the region are therefore found not in traditional industrial centers but in their peripheries. Table 1 lists Latin America's principal FTZ host cities at the dawn of the free market era as well as the dates of their initial forays into export manufacturing.

\section{Table 1 here}

What does the table reveal? FTZs have taken root in traditional agro-commercial centers and secondary cities like Cali and San Pedro Sula. While they have occasionally been imitated by residents or representatives of industrial and political capitals like Santo Domingo and Mexico City, and were later rendered redundant by more thoroughgoing free market reform at the national level (Bayer 1996; Schrank 2001), they have almost invariably been established in the hinterland in advance of - rather than response to - the abandonment of ISI. ${ }^{3}$

Municipal socialism follows the opposite pattern. While leftist presidential victories in countries like Bolivia, Brazil, Venezuela, and Uruguay have been portrayed as products of a relatively recent and unanticipated backlash against free market reform,

\footnotetext{
${ }^{2}$ Agro-commercial interests had to pay higher prices for their traditionally imported inputs and to bear the burden of overvalued exchange rates that constituted an indirect export tax (Hirschman 1968).

${ }^{3}$ Only the Salvadorans established their first FTZ near their capital.
} 
and have therefore garnered a good deal of commentary, they are in many ways the outgrowth of years of organizing and resistance in traditional working class strongholds. In fact, many of the blue- and white-collar unions that gained ground in the ISI era refused to accept defeat at the hands of free market reform. On the contrary, in several cases the groups that were bearing the burden of national neoliberalism organized to defend their prior gains at the local level through "socialist" experiments like participatory budgeting and public employment programs - and thereby lay the foundation of national leftist counterattacks down the road. ${ }^{4}$ Table 2 offers more or less parallel data on the diffusion of experiments in municipal socialism in Latin America and reveals a strong elective affinity with working class political influence.

\section{Table 2 here}

We trace variation in the success of subnational social and economic policies to variation in the organizational capacities of their principal supporters. Business incentives like FTZs tend to foster more sustainable investment, employment, and growth when they are deployed and defended by well-organized indigenous elites who have a vested interest in regional prosperity than when they are established and exploited by absentee landlords or foreign investors who are less committed to the local economy (Schrank 2005). And efforts to bolster local participation and the social wage tend to prove sustainable where the industrial working classes and their middle-class allies are organized and their antagonists are disorganized — and tend to fail where rival parties and elites are able to counterattack (Goldfrank 2007). Therefore, Figure 1 presents a stylized representation of our argument - an argument we seek to illustrate with comparative

\footnotetext{
${ }^{4}$ See Juan Pablo Luna (2007) for a similar argument that the recent rise of the Latin American left involves its ability to build a coalition of neoliberalism's "losers."
} 
historical data drawn from Brazil, the Dominican Republic, Mexico, Uruguay, and Venezuela in the pages to follow.

\section{Figure 1 here}

Our cases have been purposively selected to illustrate-rather than provide a formal test of - the plausibility of our framework. We make no effort to generalize our core claims to the rest of the region and are more interested in concept formation than in causal analysis in any event (Weber 1949). Undoubtedly, careful attention to other sets of variables and to the complexities of more individual cases - and especially the different capacities of municipal governments across countries - would be necessary to tease out the causal relationships we propose here. But we believe that concept formation is a necessary precondition of causal analysis and therefore hope that by introducing the concepts of municipal neoliberalism and socialism we will have paved the way for more systematic analyses down the road.

\section{Municipal Neoliberalism in Late Twentieth Century Latin America}

Municipal neoliberals insulate their private sector constituents from nationalist economic policies like tariffs, quotas, and foreign exchange controls by adopting or advocating subnational alternatives or safeguards. While tax breaks, duty drawbacks, and regulatory rollbacks are common, and the list of potential safeguards is all but infinite, free trade zones constitute the epitome - if by no means the sole manifestation - of neoliberal urban governance. After all, the zones offer their tenants duty free imports of capital and intermediate goods, tax breaks, and freedom from otherwise pervasive foreign exchange controls (World Bank 1992; Schrank 2001), and thereby facilitate the growth of nontraditional as well as traditional exports from otherwise inward-oriented economies. 
Puerto Rico introduced free trade zones to Latin America in the middle of the twentieth century. The so-called Economic Development Administration (Fomento) established by United States-appointed Governor Rexford Tugwell asked Arthur D. Little, Inc. (ADL), a North American consulting firm, to develop alternative employment outlets on the island. ADL proposed a strategy of "industrialization by invitation" (Dietz 1987, p. 210; see also Kahn 1986; Maldonado 1997). Fomento would lure North American transplants with tax holidays, investment subsidies, and low cost labor. North American investors would take advantage of Puerto Rico's relative cost advantage. And Puerto Ricans would reap the rewards of export, employment, and economic growth.

Observers part company over the socio-economic consequences of Puerto's Rico's effort. While mainstream economists tend to underscore the Commonwealth's precipitous postwar growth rates, and therefore label "Operation Bootstraps" an unparalleled success (Baumol and Wolff 1996), their critics underscore the persistence of poverty, inequality, and emigration, and therefore provide a more nuanced assessment (Dietz 1987). "The very success of the venture generated its stagnation," argues William Goldsmith. "It was designed to create jobs and raise industrial wages from abysmally low to just very low. In doing that, the incentive corporations previously had for relocating to Puerto Rico was destroyed" (Goldsmith quoted in Henderson 1990, p. 30). By the mid1960s, therefore, ADL had discovered - and in many ways created - a new market for offshore production sites in rival locations including Mexico, Central America, the Dominican Republic, Colombia, Taiwan, and South Korea (Schrank 2003, p. 439). ${ }^{5}$

\footnotetext{
5 ADL's rivals had entered the fray as well. See, for example, Holmes and Narver's plan for an FTZ in Saigon (Holmes and Narver 1974).
} 
Municipal authorities served as ADL's principal clients and interlocutors. While export platforms like FTZs owe their legal existence to decisions made by executive authorities in authoritarian or oligarchic environments, and therefore constitute national initiatives in theory, they owe their corporeal existence to decisions made by regional and local elites-who not only encouraged but exploited the decrees and decisions in question. Take, for example, the Border Industrialization Program that fostered the maquiladoras in northern Mexico.

A substantial body of literature treats the BIP as the federal government's response to the abolition of the US guest worker (i.e., bracero) program in the mid-1960s (Safa 1981, p. 428; Rivera-Batiz 1986, p. 263), and the threat of mass unemployment on the border certainly concentrated the minds of Mexican, as well as US, officials. But the BIP's origins actually predate the end of the bracero program by several years and owe more to the ongoing conflict between the border towns (and states) and Mexico City than to the sudden growth of discord between Mexico City and Washington.

After all, the border towns and their boosters had always felt put upon by Mexico City (Martínez 1978; Williams 1990), and their sense of outrage and injustice had only intensified in the era of ISI, urban bias, and the capital's transformation into an "urban leviathan" (Davis 1994). Furthermore, the northerners had reason to be worried. "By the 1960s," according to Edward Williams, "the once powerful role of the Norteños in the Mexico City government had diminished, suggesting that the northerners may have feared that their interests were in jeopardy" (Williams 1990, p. 308).

The governing Institutional Revolutionary Party (Partido Revolucionario Institucional, or PRI) responded to the threat of unrest on the border by appointing the 
former PRI mayor of Ciudad Juárez, Antonio Bermúdez, to design a National Frontier Program (Programa Nacional Fronterizo) in the early 1960s. Bermúdez hired ADL to formulate a regional development plan (i.e., the BIP), lobbied the central government on behalf of the plan's adoption, encouraged his friends and relatives to take advantage of the plan, and literally "morphed his cotton fields into endless square miles of windowless, single-storey boxes packed with unseen workers" (Vuillamy 2003; see also Sklair 1992; Soden et al. 1999; Schmidt 2000; Santiago Quijada 2006). While municipal elites in Mexicali, Tijuana and Matamoros reaped the rewards of the BIP as well, and therefore built their own industrial parks and plants in the late 1960s and 1970s, they lacked the "outsize influence" (Adler 2000, p. 256) of Antonio Bermúdez, and therefore continued to play catch-up for years to come. By the late 1980s, therefore, Ciudad Juárez had assumed pride of place among Mexican export platforms, and Grupo Bermúdez alone had generated almost half of the city's maquila employment (Sklair 1992, p. 99 and p. 106 note 15; see also Palmeri 1995; Dubose and Olsson 1997). ${ }^{6}$

In short, Mexico's maquiladoras are products not of neoliberalism but of ISI. The PRI's populist economic policy regime privileged political and industrial interests in the capital at the expense of agricultural and commercial interests in secondary cities like Juárez. Secondary city elites therefore organized to demand compensatory measures like tax breaks and duty drawbacks. And the PRI not only embraced but enshrined their proposal in the form of the BIP.

In fact, the causal arrow may run from the municipal neoliberalism to national neoliberalism and not vice versa (Schrank 2001), for developers and investors 'beyond

\footnotetext{
${ }^{6}$ Furthermore, Nuevo Laredo's maquilas owe whatever success they have had to the promotional effors of Sergio Arguelles Gutierrez, a Matamoros agribusinessman (see Adler 2000, p. 259).
} 
the border' responded to the BIP by demanding and taking advantage of the program's extension to the rest of the country in the 1970s and 1980s - and a number of observers have therefore attributed Mexico's abandonment of ISI and acquiescence to free trade to the "demonstration effect" offered by the maquiladoras (McKean and Fox 1994, pp. 1112 and note 3; see also Schmidt 2000). Insofar as they are correct, former President Fox's effort to incorporate hundreds of traditionally protected manufacturing enterprises into the maquila regime arguably represents the culmination—and fulfillment-of the municipal neoliberal guerrilla campaign launched in the early 1960s (Lindquist 2006).

Are FTZs and export platforms really agro-commercial reactions to the burdens imposed by ISI? Or do they represent rational efforts to take advantage of low cost labor reserves on the outskirts of major North American markets? We would obviously be naive to discount the importance of geography and transportation costs in their entirety. The maquilas have almost certainly reaped the rewards of proximity to the US market. But geography can explain neither the temporal nor the spatial origins of the BIP, for Matamoros and Tijuana are decidedly closer to North American consumers than Ciudad Juárez and are nonetheless responsible for neither the birth of the maquilas themselves nor the plurality of their employment.

The Dominican Republic offers an even more compelling rejoinder to the geographical determinists, however, for the island nation's oldest and most successful export platforms are found not in the coastal capital of Santo Domingo- home to the country's principal containerized port—-but in traditional agro-commercial centers to the north and southeast. In fact, the most successful export platforms of all are found in the inland tobacco, coffee, and cocoa trading center of Santiago - where transport costs are 
all but punitively high. What accounts for the paradox? Arthur D. Little's consultants arrived in the Dominican Republic and Mexico almost simultaneously (Schrank 2003). While they traveled to Mexico at the behest of Antonio Bermúdez in a period of relative stability, and therefore had an obvious interlocutor from the get-go, they arrived in the DR at the behest of the United States in the aftermath of the "Dominican crisis" of 1965 , and therefore confronted a different challenge (Schrank 2003).

Whom would they advise? They found their most receptive audience not in the political and industrial capital of Santo Domingo, where the late dictator Rafael Trujillo's associates continued to dominate political and economic life, but in the traditional agroexport centers to the north and southeast, where commercial family farmers cultivated coffee, tobacco, and cocoa and foreign planters cultivated sugar, respectively, for export. While industrial interests in the capital had a vested interest in tariffs and exchange controls, and therefore hoped to defend ISI from the more orthodox US advisers, their secondary city rivals paid a high price for economic nationalism, and therefore embraced at least partial liberalization (Schrank 2005).

The North Americans and the allegedly proconsular Balaguer administration ultimately agreed to a compromise. On the one hand, the North Americans would tolerate tariffs and import controls, and thereby save Santo Domingo's import-competing manufacturers from the vagaries of international competition. On the other hand, President Balaguer would tolerate free trade zones, and thereby insulate secondary city exporters (and the foreign transplants they hoped to court) from the burdens imposed by his obdurate tariff regime (Schrank 2005). 
Secondary city elites capitalized upon the passage of the legislation almost immediately. Gulf \& Western, a North American conglomerate with extensive sugar holdings in the east, responded to the imposition of foreign exchange controls by establishing the country's first FTZ with "unrepatriatable earnings" (Nelson-Horchler 1983, p. 35) in the traditional mill town of La Romana in the late 1960s and underscored the model's potential by transferring the production of nondurable consumer goods from subsidiaries in the US to the zone in the early 1970s. Municipal boosters solicited a second zone in the nearby sugar town of San Pedro de Macorís in 1973. And agrocommercial elites who were outraged by the growth of ISI and urban primacy in the capital (Moya Pons 1992) deployed a third zone in the northern city of Santiago de los Caballeros a year later.

The original zones not only prospered but inspired imitators throughout the country. By the early twenty-first century, therefore, the DR played host to approximately $50 \mathrm{EPZs}$ and their 500 tenants. While the zones in the southeastern sugar belt bear the scars of a century of dependency and exploitation, and are therefore all but entirely dominated by foreign capital, their northern counterparts are the offspring of agro-commercial elites who joined forces with (and thereby learned from) foreign manufacturing transplants in the 1970s and 1980s, and are therefore dominated by a dynamic class of indigenous investors who promise to transform their regional-if not necessarily their national—political economy (Schrank 2005; UNDP 2005).

Municipal neoliberalism is arguably a historical artifact, however, for FTZs and related incentives are apparently on the verge of extinction. On one hand, they are rendered redundant by more thoroughgoing trade reforms like the ones adopted 
throughout Latin America in the late 1980s and 1990s. On the other hand, they are constrained by the World Trade Organization and related bodies - that is, by trade agreements that are designed by skeptics who hope to hasten their demise in favor of more thoroughgoing reforms in any event (Schrank 2001; Beattie and Fifield 2005). By the late twentieth century, in fact, neoliberalism had assumed pride of place nationally and the mantle of opposition had passed from municipal neoliberalism to municipal socialism.

\section{Municipal Socialism in Contemporary Latin America}

ISI's traditional beneficiaries responded to the advent of national-level free market reform by embracing municipal socialism in the late twentieth century. Experiments in municipal socialism find commonality in a set of policies designed to expand and improve municipal services, engage in redistributive spending, increase taxes, facilitate popular participation, and generally strengthen the role of the local state. Municipal socialists extend basic services like water, sewerage, roads, and mass transit to long-neglected urban peripheries, adopt local alternatives to healthcare, education, and housing programs that have been all but abandoned by national governments, and bolster the social wage by embracing cash grants for the elderly or families of at-risk schoolchildren. Other measures including micro-credit and real estate subsidies are targeted at small businesses and cooperatives and channeled through innovative lending institutions and industry incubators.

Municipal socialists hope to pay for their various programs by undertaking fiscal reforms designed to broaden the tax base, raise marginal tax rates, render tax collection more efficient, and reduce corruption and waste in government expenditure. While their 
calls for redistribution are consistent with the demands of their populist predecessors, and have thereby provoked hostile and often ill-informed elite reactions (Economist 1998) their emphasis on "good government" resonates with the ideology of municipal socialism prevalent in Europe and North America a century ago (Bremner 1950, pp. 478-9; see also Cohn 1910; Gruber 1991; Radford 2003), and is therefore surprisingly compatible with the contemporary dictates and preferences of the international donor community.

Unlike the traditional populist or clientelist machines and parties that undergirded ISI and continued into the neoliberal era, however, and more pointedly than their European and North American predecessors, Latin America's municipal socialists emphasize - and in many ways depend upon - popular participation in local government. If free trade zones are the characteristic features of municipal neoliberalism, participatory policies-ranging from public meetings on government spending and urban planning to collaborative provision of services like cooperative housing, health clinics, and preschools - are the hallmarks of municipal socialism. Not all cities listed in Table 2 make use of each of municipal socialism's tools, of course, but most employ a combination of several elements such that a family resemblance or tendency becomes clear.

The impetus for municipal socialism can be traced not only to the failures of ISI in the 1970s but to the debt crisis and structural reforms of the 1980s and 1990s. Latin America's major cities grew rapidly under ISI - from roughly the late 1940s through the 1960s - and the region's governments offered their urban constituents a variety of benefits including food subsidies, low cost utilities, minimum wages, and collective bargaining rights. According to Susan Eckstein, the primary beneficiaries of labor market regulation included skilled workers, public employees, and the middle classes, but 
urban residents more generally gained entitlements to inexpensive housing and public services (Eckstein 2006, p. 10 and p. 35), though these were most often provided by national, not local, governments.

Of course, rapid urbanization under ISI engendered problems for local planners, including depressed growth or even population decline in city centers and rapid expansion in remote and therefore underserved shantytowns (Portes 1989, p. 8). But the problems of the ISI era paled in comparison with those of the neoliberal era inaugurated by the debt crisis of the early 1980s. After all, the various measures adopted the combat the crisis included austerity and adjustment measures that provoked declining public service provision, falling incomes, rising inflation, unemployment, and the reduction or elimination of vital subsidies and national social welfare programs (Castells, et al 1989; Villa and Rodríguez 1996; Burki and Edwards 1996; Eckstein 2006, p. 27).

Scholars have paid particularly careful attention to two responses to austerity and adjustment: organized movements for urban reform and more or less spontaneous riots against structural adjustment (see, inter alia, Eckstein 1989; Escobar and Alvarez 1992; Walton 1989; López Maya 1999a). Municipal socialism represents a third response and is particularly common in cities characterized by relatively high union density, large middle-class populations, and organized popular movements.

What accounts for the timing and location of municipal socialism? The urban working and middle-classes who were particularly hard hit by the crisis coalesced in support of new left parties in their traditional industrial and political strongholds - that is, in national capitals, industrial cities, and ports - in the late 1980s. They were united by a common interest in the vitality of the public sector and the strength of democracy. And 
they were committed to cultivating a more open and responsive political process than had been available in the past as well as to defending their traditional employment guarantees, services, and subsidies.

The fruits of their labors include a number of opposition parties formed by middle-class intellectuals and union and social movement leaders including Peru's United Left, Venezuela's Radical Cause, and Brazil's Workers' Party. These parties actively appeal to lower- and middle-class voters as well as to their activist core constituencies in the labor movement. And the participatory aspects of their experiments in municipal socialism are best interpreted as efforts to aggregate the diverse interests of the urban popular sector by creating or consolidating an identity based on active citizenship.

Elections played virtually no role in the origins of municipal neoliberalism, which emerged in an era when few countries in the region were democracies. In fact, the negotiations over the first wave of Mexican and Dominican FTZs occurred in proverbial back rooms populated by local and national elites (see, e.g., Schrank 2000; Schmidt 2000). By way of contrast, municipal socialists defended and exploited the franchise. Left parties began to experiment with municipal socialism only with the advent of democratization in the 1980s and gained ground in the 1990s as more countries introduced mayoral elections, including in capital cities, and devolved service provision to the municipal level partially in response to the swelling tide of social movements demanding popular participation and urban reform. ${ }^{7}$ In fact, the dawn of municipal socialism tended to follow hard on the heels of the introduction of meaningful multi-party mayoral elections. As early democratizers, Peruvian and Brazilian cities were the

\footnotetext{
${ }^{7}$ There is a growing literature on left parties at the local level in Latin America (see Fox 1995; Stolowicz 1999; Baiocchi 2003; Chávez and Goldfrank 2004).
} 
pioneers. Venezuelan, Uruguayan, and Argentine municipalities followed suit. And the capitals of late-democratizing Mexico and El Salvador brought up the rear.

Whether the experiments have endured and been successful or not is in part determined by the relative strength and cohesion of the local left's multi-class coalition vis-à-vis their populist predecessors and rivals. Where municipal socialists have been able to win over large segments of the poor without alienating their middle-class supporters, they have tended to stay in office. Where they have failed in either (or both) of the two goals, however, they have been defeated by traditional populist and clientelist parties that continue to use patronage rather than citizen participation as their calling card.

It should not be surprising that Brazilian cities have been at the forefront of municipal socialism. After all, Brazil experienced more dynamic industrial growth than the rest of South America in the 1960s and 1970s and thereby gave birth to a strong "new union" movement, the Workers' Party (PT), and an aggressive labor central (CUT). By the early 1980s, the PT and the CUT had gained ground in the industrial heartland of São Paulo and the surrounding "ABC Paulista" metropolitan region as well as in the nearby port city of Santos. White-collar workers including professionals, teachers, bank workers, and civil servants played a central role in both the CUT and the PT (Keck 1992, pp. 190-193). Popular movements organized around collective consumption issues proliferated in and around São Paulo and often supported labor struggles as well (Caccia Bava 1994; Keck 1992).

At the same time, however, the state of São Paulo was bearing the brunt of Brazil's crisis and restructuring. Unemployment and informalization grew rapidly, 
especially in the industrial labor force, and the state lost nearly 150,000 formal jobs in the automobile industry alone between 1986 and 1996 (Klink: on-line). Municipal socialism therefore emerged with force after the 1988 elections, in which voters in the major cities largely rejected the governing party that had overseen the crisis; the PT took São Paulo, Santos, and three of the largest ABC cities, as well as other large industrial and port cities like Porto Alegre and Vitória.

The PT mayors were either union leaders or middle-class professionals and included a psychotherapist and a social worker. They emphasized different aspects of municipal socialism in different Paulista cities. For instance, the mayor of Santos won fame for replacing the city's private bus company with a municipal corporation, creating a network of decentralized health clinics, and organizing a one-day sympathy strike in support of dockworkers facing layoffs from the nationally-mandated privatization of the port (Branford and Kucinski 1995, pp. 83-86). The mayor of Santo André introduced basic income support, a municipal micro-credit program, and an urbanization program for shantytowns (Branford and Kucinski 2003, p. 47). And the first PT mayor of São Paulo (1989-1992) built community-managed housing, improved education and healthcare (e.g., building five new hospitals), provided peripheral infrastructure and social services, and lowered the cost of public transit in part by expanding and in part by reallocating municipal spending (Kowarick and Singer 1994; Branford and Kucinski 1995, pp. 80$83) .^{8}$

\footnotetext{
${ }^{8}$ The PT doubled municipal revenue by raising and broadening the property tax, and social spending shot up from 34 percent of total municipal spending under the previous mayor to almost 50 percent under the PT. A subsequent PT mayor of Sao Paulo (2001-2004) offered income, training, and loans to poor families and the unemployed (Pochmann 2003).
} 
PT mayors simultaneously attempted to implement a variety of participatory programs including the participatory budgeting $(\mathrm{PB})$ initiatives for which their cities are by now justifiably famous. PB is characterized by public debate and (to a greater or lesser extent) determination of municipal investment and spending priorities and is perhaps most often associated with Porto Alegre, arguably the most successful case of municipal socialism in Brazil.

The PT governed Porto Alegre for four consecutive mayoral terms (1989-2004). The city's industrial history is by now familiar and provides the essential context for municipal socialism: rapid growth during the "miracle" years followed by stagnation, unemployment, informalization, and declining living conditions in the 1980s. Like São Paulo, Porto Alegre played host to a strike wave in the 1970s and contributed founding members to the PT including Olívio Dutra, a leader of the local bank workers' union and the city's first PT mayor. As Baierle (2005, p. 23) argues: “The PT came from the social movements, but its strength in Porto Alegre lay, above all, in the middle sectors (architects, journalists, bank workers, teachers, telephone workers, etc.)." While the party's leaders included residents and representatives of poor neighborhoods, including social workers and members of Catholic base communities, their impoverished neighbors had already been incorporated into a populist organization with deep local roots- the Democratic Labor Party (PDT), and the PT therefore ensured the success of municipal socialism by courting the PDT's lower-class constituency without scaring off the middleclass.

Under the PT, Porto Alegre embraced and exemplified the entire municipal socialist agenda. The city government adopted participatory budgeting and responded to 
popular preferences by extending and improving public service provision. Between the late 1980s and the late 1990s the PT almost doubled the size of the sewage networkfrom 477 miles to 850 miles - and connected 135,000 domiciles, paved 186 miles of roads, extended piped water and garbage collection services throughout the city, and increased the number of routes and riders served by the municipal bus company (Goldfrank 2002b: 292-296). Social services were expanded as well: thousands of families received public housing or land titles; the number of municipally-run schools more than tripled; a network of more than one hundred municipally-funded and cooperatively-run daycares was established; and the municipality built twenty new neighborhood health clinics and assumed control of the local healthcare system from the state government (Goldfrank 2002b: 294-295). The city government opened a microcredit bank, built an incubator for small industrial ventures, and started a recycling cooperative. And the PT paid for it all with progressive taxation and a crackdown on evasion (Goldfrank 2002b, pp. 227-228). Finally, the city's achievements-and particularly its participatory budgeting process-attracted admirers and imitators in scores of cities throughout Brazil and beyond (Goldfrank 2006).

The expansion of infrastructure and services in Porto Alegre had a strongly redistributive cast, for the participatory budgeting criteria allocated spending to areas with the greatest needs. Many of the city's poorest neighborhoods were visibly transformed. And ecological analyses of voting patterns reveal that over the years the PT has assumed the PDT's traditional position as the most popular party in lower-class neighborhoods. The PT also maintained a plurality in the middle-class neighborhoods where it originally performed best until 2004, when the historically weak opposition at 
last accepted many of the PT's programs and the PT mayoral candidate saw his share of the vote in middle- and upper-class neighborhoods plummet by 10 to 12 percentage points (Baierle 2005, p. 41). Middle-class voters essentially defected from the multi-class coalition undergirding municipal socialism and cost the PT the race. While the new mayor has retained a number of trademark PT policies, including participatory budgeting, he has also promised a more business-friendly administration. And the PT has offset its losses in Porto Alegre by winning 411 cities in the 2004 elections and thereby gaining hundreds of new laboratories in which to experiment.

A history of decentralized federalism renders Brazil a particularly likely breeding ground for municipal socialist experiments. But similar experiments have emerged in less likely contexts and provide support for our belief that the timing and character of municipal socialism are shaped by legacy of ISI and the organizational capacity of the working- and middle-class alliance.

Uruguay boasts perhaps the most successful case of municipal socialism outside of Brazil. The Broad Front (FA) has governed the capital of Montevideo since Tabaré Vázquez, who is currently the country's president, won the 1989 mayoral election as voters rejected national-level neoliberal reforms. The FA unites several political parties that have strong union and social movement bases including the Communists and the Socialists and in many respects resembles the PT. And FA administrations have transformed Montevideo in ways similar to those described above for Porto Alegre with similar tools (Goldfrank 2002a).

Furthermore, the FA and the PT share common organizational histories. Like the PT, the FA started out stronger in middle-class neighborhoods than in poorer areas (with 
the exception of one union stronghold) and gained ground among the poor after winning elected office and redistributing income through infrastructural development and the provision of social services (Luna 2004, p. 19). ${ }^{9}$ While Uruguay's traditional parties, the Colorados and Blancos, successfully blocked the FA's most far-reaching participatory programs and tax reforms, they failed to provide a strong alternative to municipal socialism and therefore lost ground to the FA over time. As Luna (2004, p. 21) notes, "the clientelistic apparatuses of both traditional parties atrophied as a result of the economic crisis."

Venezuelan cities provide parallels as well as contrasts. Like Brazil and Uruguay, Venezuela gave birth to a left leaning party with strong ties to dissident labor unions in the late twentieth century (Hellinger 1996). While representatives of the Radical Cause (CR), as the party is known, assumed control of traditional industrial centers in the early 1990s, and tried to implement municipal socialism in Ciudad Guayana and Caracas, they were decidedly more successful in the former than the latter. After all, Ciudad Guayana had been established in 1961 as part of the national state's effort to expand industrialization and therefore featured stronger industrial unions and weaker traditional party organizations than the capital. The CR, and later a splinter party committed to municipal socialism, governed Ciudad Guayana for over a decade (four consecutive terms) and implemented a number of distributive policies including participatory budgeting and investment in working class neighborhoods (López Maya 1999b). By way of contrast, the CR achieved little in Caracas and failed to gain re-election (Goldfrank 2002b).

\footnotetext{
${ }^{9}$ See Goldfrank (2002b, pp. 202-205) for quantitative analyses of the relationship between poverty and spending in Montevideo.
} 
What accounts for the CR's failure in the capital in the mid-1990s? While party activists embraced municipal socialism in theory, and therefore adopted participatory budgeting measures, they treated the middle classes as their core constituents in practice, and therefore distributed their per capita investments in a "need blind" manner (Goldfrank 2002b, p. 135-137). As a result, the CR failed to attract lower class support and opened the door to a counterattack from traditional parties like Acción Democrática (AD) that had always been stronger in Caracas than Ciudad Guayana in any event.

\section{Conclusion}

Max Weber believed that the social sciences advanced through the construction, critique, and reformulation of the "concepts through which we seek to comprehend reality" (Weber 1949, pp. 105-6). We have deployed the concepts of municipal neoliberalism and municipal socialism in an effort to comprehend Latin American reality and we therefore believe that our paper's principal contributions are conceptual — that is, that one can find value in the concepts of municipal neoliberalism and municipal socialism without embracing our account of their origins and consequences.

We have nonetheless advanced a preliminary account of the origins of urban policy regimes in late twentieth century Latin America as well. Our account is bivariate. The first variable - the municipality's traditional orientation to the world economydictates policy preferences. While traditionally outward-oriented cities paid a particularly high price for economic nationalism, and therefore responded to ISI by deploying FTZs in the 1960s and 1970s, their traditionally inward-oriented rivals bore the brunt of austerity and structural adjustment, and therefore adopted distributive countermeasures in the subsequent era of national neoliberal reform. The second 
variable - the organizational capacities of municipal classes and sectors-determines the degree to which urban elites and activists are able to translate their preferences into reality. While domestically controlled export sectors are likely to be particularly wellorganized, and therefore tend to engender more successful neoliberal experiments than their foreign-controlled counterparts, insurgent parties in cities with broadly based class structures are likely to be particularly encompassing, and therefore tend to engender more sustainable socialist experiments than their more narrowly based counterpartsespecially when they emerge in weak party systems (e.g., Brazil).

One need not understand the origins of municipal policy regimes to recognize their salience, however, and an astute observer will draw at least three conclusions from the neoliberal and socialist experiments we have identified whether or not he or she agrees with our interpretation of their origins and degree of success. First, national economic policy regimes do not penetrate their national territories in a homogeneous fashion; on the contrary, they tend to accommodate, reproduce, and in some cases magnify subnational variation. Second, subnational political and economic experiments are as likely to produce as to be products of the national policies they resemble, for dissident municipalities that pay the price for policy reforms offer their residents space in which to defend their historical gains and launch nationwide counterattacks. And, third, the "subnational comparative method" is therefore an essential counterweight to "whole nation bias" as well as a useful source of additional degrees of freedom (Snyder 2001; Gibson 2005).

What, then, does the future hold for Latin American cities? We can envision two distinct possibilities. On the one hand, local authorities in traditional export centers like 
Maracaibo, Venezuela (Gonzalez 2003), Guayaquil, Ecuador (de la Torre 2008), and Santa Cruz, Bolivia (Eaton 2007) are responding to the resurgence of the left at the national level with renewed calls for autonomy at the local level in order to protect against advancing statist agendas. So far their campaigns have been limited in both scope and influence, except in Bolivia, where other provinces have joined Santa Cruz in holding autonomy referenda. If these efforts gain traction, they could well constitute the shock troops of a renewed cycle of municipal neoliberalism-with attendant consequences for national politics down the road.

On the other hand, municipal authorities elsewhere in Latin America are converging upon a common set of tools derived from both the neoliberal and socialist toolkits. After all, the archetypal institutions of both urban policy regimes-FTZs and participatory budgeting — have proliferated throughout the region, yielding interesting, but very new, hybrids that would be fascinating cases for further research. For example, cities with earlier experiments in municipal socialism like Ciudad Guayana and Estelí, Nicaragua have recently opened tax-free industrial zones. Porto Alegre's new post-PT mayor offers large corporations generous tax breaks (Chavez 2006). And literally hundreds of Latin American cities have adopted participatory budgeting initiatives (Goldfrank 2006). Maquila owners were among the primary champions of PB in Santiago de los Caballeros in the Dominican Republic, which went on to pass a law in 2007 requiring PB in all Dominican municipalities. In El Salvador, municipal governments from across the political spectrum play host to both FTZs and participatory budgeting.

The apparent convergence of local neoliberal and socialist experiments may derive from the shortcomings of each strategy when pursued in isolation. While 
neoliberalism undercuts the social safety net and contributes to the atomization orworse, from the employer's perspective-mobilization of the citizenry, socialism undercuts investment and renders the creation of income-generating activity less likely. The current convergence may therefore represent a Polanyian "double movement" (Polanyi 1944). Efforts to marketize Latin America at all costs have been reined in by efforts to provide at least minimal social safety nets-but the knitters of those nets seem to recognize that the market is better cushioned than repressed. ${ }^{10}$ While these experiments are still in process, and face myriad opponents and obstacles, they have a good deal of potential, and advocates of sustainable alternatives to both neoliberalism and populism at the national level would therefore do well to look toward the local level for their models. It is in the cities, and not the legislatures and national palaces, that we will find the most numerous, diverse, and interesting experiments.

\footnotetext{
${ }^{10}$ In addition to municipal policymakers, international policymakers in institutions like the World Bank seem to appreciate the need for policies for both development and distribution, as the Bank and other development institutions have begun to push both FTZs and PB, which helps explain their ubiquity.
} 


\section{Bibliography}

Adler, Bill. 2000. Mollie's Job: A Story of Life and Work on the Global Assembly Line.

New York: Simon and Schuster.

Antiago Quijada, Guadalupe. 2006. “Antecedentes de la industria maquiladora.” CITTAC. April 9.

Baierle, Sérgio. 2005. "Lutas em Porto Alegre: entre a revolução política e o transformismo." MAPAS Project Report. December.

Baiocchi, Gianpaolo, ed. 2003. Radicals in Power: The Workers' Party and Experiments with Urban Democracy in Brazil (London and New York: Zed Books).

Baumol, William, and Edward Wolff. 1996. "Catching Up in the Postwar Period: Puerto Rico as the Fifth 'Tiger.'” World Development. 24 (5): 869-85.

Bayer, Alex. 1996. "The dark side of ex-im centers." Treasury \& Risk Management. September.

Beattie, Alan, and Anna Fifield. 2005. "Zone alone.” Financial Times. May 12.

Branford, Sue, and Bernardo Kucinski. 2003. Politics Transformed: Lula and the Workers' Party in Brazil (London: Latin American Bureau).

Branford, Sue, and Bernardo Kucinski. 1995. Brazil: Carnival of the Oppressed (London: Latin American Bureau).

Braütigam, Deborah. 2004. “The People’s Budget? Politics, Participation, and Pro-Poor Policy." Development Policy Review. 22 (6): 653-68. 
Bremner, Robert. 1950. "The Civic Revival in Ohio: Municipal Ownership and Economic Privilege.” American Journal of Economics and Sociology. 9 (4): $477-$ 82.

Bridges, Tyler. 1987. "Chile trade zone turns small town into booming city." Christian Science Monitor. November 24.

Business Week. 1979. “What lures industry to Brazil's Northeast?” April 16.

Caccia Bava, Sílvio. 1994. "Neighborhood Movements and the Trade Unions: The São Bernardo Experience," in Lúcio Kowarick, ed., Social Struggles and the City: The Case of São Paulo (New York: Monthly Review Press).

Catanese, Anthony. 1973. "Planning in a State of Siege: The Colombia Experience." Land Economics. 49 (1): 35-43.

Chavez, Daniel. 2006. "Participation Lite: The Watering Down of People Power in Porto Alegre," Red Pepper (May).

Chavez, Daniel, and Benjamin Goldfrank, eds. 2004. The Left in the City: Participatory Local Governments in Latin America (London: Latin American Bureau and Transnational Institute).

Christopherson, Susan. 1994. "The fortress city. Privatized spaces, consumer citizenship.” Pp. 409-27 in A. Amin, ed., Post-Fordism. A Reader. Oxford: Blackwell

Cohn, Gustav. 1910. "Municipal Socialism.” The Economic Journal, Vol. 20, No. 80. (Dec., 1910), pp. 561-568.

Coone, Tim. 1987. "Honda Close To Deal On Argentine Plant.” Financial Times. June 10. 
Davis, Diane. 1994. Urban Leviathan: Mexico City in the Twentieth Century. Philadelphia: Temple University Press.

De la Torre, Patricia. 2008. "La autonomía guayaquileña." El Telégrafo. June 12, 2008.

Dietz, James. 1987. Economic History of Puerto Rico: Institutional Change and Capitalist Development. Princeton: Princeton University Press.

Dubose, Louis, and Karen Olsson. 1997. "Border Games.” Civilization. 4 (4): 38-46.

Eaton, Kent. 2007 "Backlash in Bolivia: Regional Autonomy as a Reaction against Indigenous Mobilization.” Politics \& Society. 35: 71-102.

Eckstein, Susan, ed. 1989. Power and Popular Protest: Latin American Social Movements (Berkeley: University of California Press).

Eckstein, Susan. 2006. "Urban Resistance to Neoliberal Democracy Across Latin America." Prepared for delivery at the 2006 Meeting of the Latin American Studies Association. San Juan, Puerto Rico, March 15-18.

Economist. 1987. "But Quito isn't Guayaquil, alas.” December 26.

Economist. 1998. "New ideas for the old left." January 17.

Economist. 1999. "Under the volcano.” November 27.

Economist. 2001. "A Country Apart." April 21.

Enyeart, John. 2003. "Revolution or Evolution: The Socialist Party, Western Workers, and Law in the Progressive Era," Journal of the Gilded Age and Progressive Era. October. 
Escobar, Arturo, and Sonia Alvarez, eds. 1992. The Making of Social Movements in Latin America: Identity, Strategy, and Democracy (Boulder, San Francisco, and Oxford: Westview Press).

Evans, Peter. 2002. Livable Cities? Urban Struggles for Livelihood and Sustainability. Berkeley: University of California Press).

Fainstein, Susan. 1992. Divided Cities: New York and London in the Contemporary World. Oxford: Blackwell.

Florida, Richard. 2002. The rise of the creative class. New York: Basic Books.

Forero, Juan. 2004. “In Bolivia's Elitist Corner, There's Talk of Cutting Loose.” New York Times. August 24.

Fox, Jonathan. 1995. "The Crucible of Local Politics," NACLA: Report on the Americas. 29:1 (July-August).

Gibson, Edward. 2005. "Boundary Control: Subnational Authoritarianism in Democratic Countries.” World Politics. 58: 101-32.

Goldfrank, Benjamin. 2002a. "The Fragile Flower of Local Democracy: A Case Study of Decentralization/Participation in Montevideo," Politics \& Society, 30:1 (March): 51-83.

Goldfrank, Benjamin. 2002b. Urban Experiments in Citizen Participation, Ph.D. Dissertation, Political Science, University of California, Berkeley. Goldfrank, Benjamin. 2004. "Conclusion: The End of Politics or a New Beginning for the Left?" In Chavez and Goldfrank, eds., The Left in the City (London: Latin American Bureau and Transnational Institute). 
Goldfrank, Benjamin. 2006. “Los procesos de 'presupuesto participativo' en América Latina: Éxito, fracaso y cambio,” Revista de Ciencia Política, 26:2, Chile (December): 3-28.

Goldfrank, Benjamin. 2007. “The Politics of Deepening Local Democracy: Decentralization, Party Institutionalization, and Participation." Comparative Politics, 39 (January): 147-68.

Gonzalez, David. 2003. "Maracaibo Oil Region a Crucial Battleground for Chavez as Venezuelan Conflict Rages ." New York Times. February 28.

Gruber, Helmut. 1991. Red Vienna: Experiment in Working-Class Culture, 1919-1934. New York: Oxford University Press.

Hall, Tim, and Phil Hubbard. 1996. "The entrepreneurial city: new politics, new urban geographies.” Progress in Human Geography. 20: 153-174

Harris, Nigel. 1997. "Cities in a global economy: Structural change and policy reactions." Urban Studies. 34 (1): 1693-1703.

Heller, Patrick. 1995. "From Redistribution to Class Compromise: Redistribution and Growth in a South Indian State." Journal of Development Studies. 31 (5): 64572.

Hellinger, Daniel. 1996. "The Causa R and the Nuevo Sindicalismo in Venezuela," Latin American Perspectives, Issue 90, 23:3 (Summer): 110-131.

Henderson, Zorika. 1990. "Enterprise Zones Are Pie-in-the-Sky Solutions to Poverty." Human Ecology. 18 (3): 30-31.

Hirschman, Albert. 1968. "Political Economy of Import-Substituting Industrialization in Latin America." Quarterly Journal of Economics. 
Holmes and Narver. 1974. Saigon export processing zone planning study. Saigon: USAID Mission to Vietnam.

Jeroen Klink. Online. "Re-inventing Regional Planning in a Context of Local Economic Restructuring: The Case of the Greater ABC Region, Sao Paulo, Brazil,” City Matters. $<$ http://www.urbanicity.org/FullDoc.asp?ID=317> Accessed August 23, 2006.

Judd, Richard William. 1989. Socialist Cities: Municipal Politics and the Grass Roots of American Socialism. Albany: State University of New York.

Kahn, E.J. 1986. The Problem Solvers: A History of Arthur D. Little. Boston: Little Brown.

Keck, Margaret. 1992. The Workers' Party and Democratization in Brazil (New Haven and London: Yale University Press).

King, Gary, Robert Keohane, and Sidney Verba. 1994. Designing Social Inquiry: Scientific Inference in Qualitative Research. Princeton: Princeton University Press.

Kowarick, Lúcio, and André Singer. 1994. "The Workers’ Party in São Paulo," in Lúcio Kowarick, ed., Social Struggles and the City: The Case of São Paulo (New York: Monthly Review Press).

Lee, Cristina. 1989. "Big Argentine province pursues US trade ties." Journal of Commerce. March 3.

Lindquist, Diane. 2006. "Fox decree may revitalize maquiladora industry." San Diego Union Tribune. August 16. 
López Maya, Margarita, ed. 1999a. Lucha popular, democracia, neoliberalismo: protesta popular en América Latina en los años de ajuste (Caracas: Editorial Nueva Sociedad).

López Maya, Margarita. 1999b. “Alcaldías de Izquierda en Venezuela: Gestiones Locales de La Causa Radical (1989-1996)," in Beatriz Stolowicz, ed., Gobiernos de izquierda en América Latina: El Desafío del Cambio (México, DF: Plaza y Valdés Editores).

Low, Setha. 1997. "Urban Fear: Building the Fortress City." City and Society. 9 (1): 53-71.

Luna, Juan Pablo. 2007. "Frente Amplio and the Crafting of a Social Democratic Alternative in Uruguay.” Latin American Politics \& Society. 49 (4): 1-30.

Luna, Juan Pablo. 2004. "Between the sword and the wall? The recent transformation of Frente Amplio's social base and some implications for the Latin American left." Paper presented at the Working Group on Political and Economic Regimes in Latin America at UNC Chapel Hill. November.

MacLeod, Gordon. 2002. "From Urban Entrepreneurialism to a 'Revanchist City’? On the Spatial Injustices of Glasgow's Renaissance.” Antipode. 34 (3): 602-24.

Magee, John. 1985. Arthur D. Little, Inc.: At the Moving Frontier. New York: Newcomen Society.

Maldonado, A.W. 1997. Teodoro Moscoso and Puerto Rico's Operation Bootstrap. Gainesville: University Press of Florida. Markey, Patrick. 2005. "In Bolivia, Rich West Demands Autonomy.” Washington Post. February 6. 
Martínez, Oscar. 1978. Border Boom Town: Ciudad Juárez since 1848. Austin: University of Texas Press.

Mayer, Margit. "Post-Fordist City Politics." Pp. 316-37 in A. Amin, ed., Post-Fordism. A Reader. Oxford: Blackwell

McKean, Cressida, and James Fox. 1994. Export and Investment Promotion Services: Do They Work? Washington: USAID.

Menocal, Alina Rocha. 2004. "A new wave of decentralization in Latin America? A conversation with Rosemary Thorp.” Development in Practice. 14 (6): 724-32.

Montero, Alfred. 2001. 'Making and Remaking 'Good Government' in Brazil: Subnational Industrial Policy in Minas Gerais.” Latin American Politics and Society. 43 (2):

Moya Pons, Frank. 1992. Empresarios en conflicto: Políticas de industrialización y sustitución de importaciones en la República Dominicana. Santo Domingo: Fondo para el Avance de las Ciencias Sociales, Inc.

Nelson-Horchler, Joani. 1983. "US Multinationals: Benefactors or Bandits?” Industry Week. April 18. p. 35.

Ocampo, José Antonio, and Juan Martín. 2003. A Decade of Light and Shadow. Latin America and the Caribbean in the 1990s. Santiago: CEPAL.

Palmeri, Christopher. 1995. "The Flip Side of Devaluation.” Forbes. 155 (4): 44-5. Pinnock, Don. 1989. "Ideology and urban planning: blueprints for a garrison city." Pp. 150-68 in W. James. and M. Simons, eds., The Angry Divide. Cape Town: David Philips. 
Piore, Michael. 2005. "Normas laborales de Mexico en la economía global." Comercio Exterior. 55 (2): 140-7.

Pochmann, Marcio, ed. 2003. Outra Cidade é Possível: Alternatias de Inclusão Social em São Paulo (São Paulo: Cortez Editora).

Polanyi, Karl. 1944. The Great Transformation: The Political and Economic Origins of Our Time (Boston: Beacon Press).

Portes, Alejandro. 1989. "Latin American Urbanization in the Years of the Crisis," Latin American Research Review, 24:3.

Quilley, Stephen. 2000. “Manchester First: From Municipal Socialism to the Entrepreneurial City," International Journal of Urban and Regional Research, Vol 24, No. 3. $601-615$.

Radford, Gail. 2003. "From Municipal Socialism to Public Authorities: Institutional Factors in the Shaping of American Public Enterprise," Journal of American History Vol. 90, No. 3, December.

Rivera-Batiz, Francisco. 1986. "Can Border Industries Be a Substitute for Immigration?" American Economic Review. 76 (2): 263-8.

Roberts, Bryan, and Alejandro Portes. 2005. "Coping with the Free Market City: Collective Action in Six Latin American Cities at the End of the Twentieth Century." Latin American Research Review. 41 (2): 57-83.

Safa, Helen. 1981. "Runaway Shops and Female Employment: The Search for Cheap Labor." Signs. 7 (2): 418-33.

Sassen, Saskia. 1991. The Global City: New York, London and Tokyo. Princeton: Princeton University Press. 
Schmidt, Samuel. 2000. In Search of Decision: The Maquiladora Industry in Mexico. Juárez, Chihuahua: UACJ/Flagstaff Institute.

Schrank, Andrew. 2000. Urban Bias, Hinterland Response: Social Organization and Export Diversification in the Dominican Republic. Unpublished PhD dissertation. Department of Sociology. University of Wisconsin, Madison.

Schrank, Andrew. 2001. "Export Processing Zones: Free Market Islands or Bridges to Structural Transformation?" Development Policy Review. 19 (2): 223-42.

Schrank, Andrew. 2003. "Foreign investors, 'flying geese,' and the limits to export-led industrialization in the Dominican Republic." Theory and Society. 32: 415-43.

Schrank, Andrew. 2005. "Entrepreneurship, Export Diversification, and Economic Reform: The Birth of a 'Developmental Community' in the Dominican Republic." Comparative Politics. 38 (October): 43-62.

Schumacher, Edward. 1983. "City in Argentina lives up to its rebellious image." New York Times. November 12.

Scott, Allen. "Creative Cities: Conceptual Issues and Policy Questions." Journal of Urban Affairs. 28 (1): 1-17.

Sheahan, John. 1987. Patterns of Development in Latin America: Poverty, Repression, and Economic Strategy. Princeton: Princeton University Press.

Siri, Gabriel. 2000. "Employment and Social Investment Funds in Latin America." SETP No. 7. Geneva: ILO.

Sklair, Leslie. 1992. "The Maquilas in Mexico: A Global Perspective.” Bulletin of Latin American Research. 11 (1): 91-107. 
Snyder, Richard. 2001. "Scaling Down: The Subnational Comparative Method." Studies in Comparative International Development. 36 (1): 93-110.

Soden, Dennis, et al. 1999. "The Delphi Decision: A Case Study.” IPED Technical Report 99-5. Public Policy Research Center. El Paso: UTEP.

Soja, Edward. 1995. "Postmodern Urbanization: The Six Restructurings of Los Angeles.” Pp. 125-37 in S. Watson and K. Gibson, eds., Postmodern Cities and Spaces. Oxford: Blackwell.

Stansbury, Burke. 2006. "El Salvador: Elections and the FMLN." NACLA Report on the Americas. 39 (6): 45-6.

Stolowicz, Beatriz, ed. 1999. Gobiernos de izquierda en América Latina: El Desafío del Cambio (México, DF: Plaza y Valdés Editores).

Tendler, Judith, and Rodrigo Serrano. 1999. "The Rise of Social Funds: What are they a model of?" MIT/UNDP Decentralization Project. 1999.

Tendler, Judith. 2000. "Why are social funds so popular?” Pp. 114-29 in Yusuf and Evenett, eds., Local Dynamics in an Era of Globalization: 21st Century Catalysts for Development. Washington: World Bank.

Tendler, Judith. 2002. "Small Firms, the Informal Sector, and the Devil's Deal." IDS United Nations Development Programme (UNDP). 2005. República Dominicana: Informe Nacional de Desarrollo Humano 2005: Hacia una inserción mundial incluyente y renovada. Santo Domingo: PNUD.

Villa, Miguel, and Jorge Rodríguez. 1996. "Demographic trends in Latin America's metropolises, 1950-1990." In Alan Gilbert, ed., The mega-city in Latin America 
(Tokyo, New York, and Paris: United Nations University Press). On-line: http://www.unu.edu/unupress/unupbooks/uu23me/uu23me00.htm\#Contents

Vuillamy, Edward. 2002. "Dispatches: The Lawless Mexican Border Town of Juarez Is No Stranger to Death.” Observer Magazine (Guardian Newspaper). March 9.

Walton, John. 1989. "Debt, Protest, and the State in Latin America," in Susan Eckstein, ed., Power and Popular Protest: Latin American Social Movements (Berkeley: University of California Press).

Wampler, Brian, and Leonardo Avritzer. 2004. "Participatory Publics: Civil Society and New Institutions in Democratic Brazil," Comparative Politics, 36 (April): 291312.

Weber, Max. 1949. The Methodology of the Social Sciences. New York: Free Press.

Weitzman, Hal. 2006. "Cheers and faint war drums as Santa Cruz dreams of autonomy." Financial Times. July 1.

Wheatley, Jonathan. 1997. “'Tiger' economies of NE Brazil” Financial Times. December 11.

Williams, Edward. 1990. “The Resurgent North and Contemporary Mexican Regionalism.” Mexican Studies. 6 (2): 299-323.

World Bank. 1992. Export Processing Zones. Washington: World Bank. 
Table 1: FTZ host cities by country, circa 1990.

\begin{tabular}{|c|c|c|}
\hline Country & Location & Year first zone established \\
\hline Brazil & Manaus & 1967 \\
\hline Chile & Iquique & 1975 \\
\hline \multirow[t]{6}{*}{ Colombia } & Baranquilla & 1964 \\
\hline & Cucutá & 1972 \\
\hline & Buenaventura & 1973 \\
\hline & Cali & 1974 \\
\hline & Santa Marta & 1974 \\
\hline & Cartagena & 1978 \\
\hline \multirow[t]{5}{*}{ Costa Rica } & Puerto Moin & 1977 \\
\hline & El Roble (near Puntarenas) & 1980-1985 \\
\hline & Cartago & 1985 \\
\hline & Alajuela & 1988 \\
\hline & San José & 1989 \\
\hline \multirow[t]{14}{*}{ Dominican Republic } & La Romana & 1968 \\
\hline & San Pedro de Macorís & 1973 \\
\hline & Santiago & 1974 \\
\hline & Puerto Plata & 1983 \\
\hline & Baní & 1986 \\
\hline & San Cristóbal & 1986 \\
\hline & Santo Domingo & 1986 \\
\hline & La Vega & 1987 \\
\hline & Bonao & 1988 \\
\hline & Esperanza & 1988 \\
\hline & Moca & 1988 \\
\hline & Villa Altagracia & 1988 \\
\hline & Barahona & 1989 \\
\hline & San Francisco de Macorís & 1989 \\
\hline El Salvador & San Bartolo (near San Salvador) & 1973 \\
\hline \multirow[t]{2}{*}{ Guatemala } & Santo Tómas de Castilla & 1972 \\
\hline & La Unión & 1989 \\
\hline \multirow[t]{2}{*}{ Honduras } & Puerto Cortes & 1972 \\
\hline & San Pedro Sula & $1980 \mathrm{~s}$ \\
\hline \multirow[t]{2}{*}{ Mexico } & Northern border (20 km. limit) & 1965 \\
\hline & Expansion to remainder of country & 1972 \\
\hline
\end{tabular}

Sources: Bridges (1987); World Bank 1992 (Table A3); Bayer (1996); and Schrank (2001). The unit of analysis is the city; some cities feature multiple zones. Mexico gave individual factories as well as industrial parks "maquiladora" (or FTZ) status; however, only factories and parks within 20 kilometers of the border qualified for free zone status prior to 1972. 
Table 2: Selected Cases of Municipal Socialism in Latin America

\begin{tabular}{|c|c|c|}
\hline Municipality & Party & Years in Office \\
\hline Location & Party or coalition & Time frame \\
\hline $\begin{array}{l}\text { Ciudad Guayana (Mun. } \\
\text { Caroní), Venezuela }\end{array}$ & Causa Radical; Patria Para Todos & $\begin{array}{l}1989-1997 ; 1998-2001,2004- \\
\text { Present }\end{array}$ \\
\hline $\begin{array}{l}\text { Caracas (Mun. Libertador), } \\
\text { Venezuela }\end{array}$ & $\begin{array}{l}\text { Causa Radical; Partido Socialista } \\
\text { Unido de Venezuela }\end{array}$ & $1993-1995 ;$ 2000-Present \\
\hline Lima, Peru & Izquierda Unida & $1984-1986$ \\
\hline Ilo, Peru & Izquierda Unida; Fuerza Ilo & $1981-1989 ; 1990-2001$ \\
\hline Rosario, Argentina & Partido Socialista (Popular) & 1989 - Present \\
\hline Montevideo, Uruguay & Frente Amplio & 1990 - Present \\
\hline Mexico City, Mexico & $\begin{array}{l}\text { Partido de la Revolución } \\
\text { Democrática }\end{array}$ & 1997 - Present \\
\hline Bogotá, Colombia & Polo Democrático Independiente & 2003 - Present \\
\hline San Salvador, El Salvador & $\begin{array}{l}\text { Frente Farabundo Martí para la } \\
\text { Liberación Nacional }\end{array}$ & 1998 - Present \\
\hline Estelí, Nicaragua & $\begin{array}{l}\text { Frente Sandinista de Liberación } \\
\text { Nacional }\end{array}$ & 1979 - Present \\
\hline Porto Alegre (RS), Brazil & Partido dos Trabalhadores & $1989-2004$ \\
\hline São Paulo (SP), Brazil & Partido dos Trabalhadores & $1989-1992 ; 2001-2004$ \\
\hline Belo Horizonte (MG), Brazil & $\begin{array}{l}\text { Partido dos Trabalhadores; Partido } \\
\text { Socialista Brasileira; PT }\end{array}$ & $\begin{array}{l}1993-1996 ; 1996-2002 ; 2002- \\
\text { Present }\end{array}$ \\
\hline Brasília (DF), Brazil & Partido dos Trabalhadores & $1995-1998$ \\
\hline São Bernardo (SP), Brazil & Partido dos Trabalhadores & $1989-1992$ \\
\hline Mauá (SP), Brazil & Partido dos Trabalhadores & $1997-2004$ \\
\hline Santos (SP), Brazil & Partido dos Trabalhadores & $1989-1996$ \\
\hline Diadema (SP), Brazil & $\begin{array}{l}\text { Partido dos Trabalhadores; Partido } \\
\text { Socialista Brasileiro; PT }\end{array}$ & 1983 - Present \\
\hline Santo André (SP), Brazil & Partido dos Trabalhadores & $1989-1992,1996-$ Present \\
\hline Vitória (ES), Brazil & Partido dos Trabalhadores & 1989-1992; 2005 - Present \\
\hline Belém (PA), Brazil & Partido dos Trabalhadores & $1996-2004$ \\
\hline
\end{tabular}


Figure 1: A typology of urban political economies in contemporary Latin America

\begin{tabular}{|c|c|c|c|}
\hline \multirow{4}{*}{ 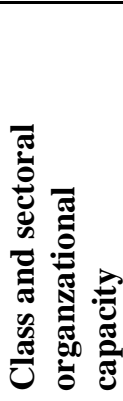 } & & \multicolumn{2}{|c|}{ Municipal orientation vis-à-vis world economy } \\
\hline & & Inward & Outward \\
\hline & 昰 & Successful municipal socialism & Successful municipal neoliberalism \\
\hline & $\stackrel{3}{\rho}$ & Unsuccessful municipal socialism & Unsuccessful municipal neoliberalism \\
\hline
\end{tabular}

